\title{
Flash Flood Risk Assessment of Wadi Degla Basin Protected Area, East of Maadi, Cairo, Egypt Based on Morphometric Analysis Using GIS Techniques
}

\author{
Abdel Galil Abdel Hamid Hewaidy ${ }^{1}$, Mohamed Abu El Hassan ${ }^{2}$, Ahmed Salama ${ }^{3}$, Ragab Ahmed ${ }^{4}$, \\ ${ }^{1}$ Department of Geology, Faculty of Science, Al-Azhar University, Cairo, Egypt \\ ${ }^{2}$ Department of Geology Faculty of Science, Monofia University, Monofia, Egypt \\ ${ }^{3}$ Nature Conservation Sector, Egyptian Environmental Affairs Agency, Cairo, Egypt \\ ${ }^{4}$ Geology Department Faculty of Science, Monofia University, Monofia, Egypt
}

Email address:

ahewaidy50@yahoo.com (A. G. A. Hewaidy), abouelhassanmohamed@gmail.com (M. A. El Hassan), maazapark@yahoo.com (A. Salama), ragabahmed3377@ygmail.com (R. Ahmed)

${ }^{*}$ Corresponding author

\section{To cite this article:}

Abdel Galil Abdel Hamid Hewaidy, Mohamed Abu El Hassan, Ahmed Salama, Ragab Ahmed. Flash Flood Risk Assessment of Wadi Degla Basin Protected Area, East of Maadi, Cairo, Egypt Based on Morphometric Analysis Using GIS Techniques. Hydrology.

Vol. 9, No. 3, 2021, pp. 66-73. doi: 10.11648/j.hyd.20210903.12

Received: July 15, 2021; Accepted: August 5, 2021; Published: August 13, 2021

\begin{abstract}
The Wadi Degla basin is amongst the most important basins in the north-eastern part of the Eastern Desert, east of Maadi, Cairo, which drains into River Nile. It covers an area of about $177.6 \mathrm{~km}^{2}$. Although it located in an arid region, the basin could receive a huge amount of rainwater during heavy rainstorms which in turn lead to initiate flash flood hazard and causing catastrophic effects on existing infrastructure of main gate and tracks of protected area, also threatened visitor's life and surrounding environments. The present study aims to evaluate of flash flood risk in Wadi Degla and possible mitigation. The morphometric parameters investigation were carried out using ASTER Digital Elevation Model (DEM), GIS, and geomorphic field observations. Using a technique given by El-Shamy, the risk degree for the Wadi Degla basin's vulnerability to flash flooding risk was calculated. The first technique focuses on the relationship between drainage density and bifurcation ratio, whereas the second relies on the relationship between drainage frequency and bifurcation ratio. For the examined basin of the watershed, the third morphometric parameter (the bifurcation ratio, drainage density, and stream frequency) were obtained and calculated. The bifurcation ratio, stream frequency, and drainage density all have values of 1.7, 6.05, and 2 according to morphometric study. The bifurcation ratio, stream frequency, and drainage density have morphometric values of 1.7, 6.05, and 2 respectively, as per morphometric analysis. The Wadi Degla has elongated shape. According to the computed metrics (e.g., stream frequency, bifurcation ratio and drainage density), the Wadi Degla basin catchment area falls into category (A). This means that there is expected high susceptibility of flash flooding possibility in the area under consideration. This expected risk leads the Ministry of Water Resources and Irrigation to establish three dams on the pass of Wadi Degla to work as an obstacle for decrease the flash flood velocity flow. Consequently, from an environmental hazards point of view, the Wadi Degla Protected Area should be closed during heavy rainfall for visitor safety and also avoid the establishment of any basic infrastructure in the vicinity of the Wadi pass.
\end{abstract}

Keywords: Flash Foods, GIS, Morphometric Analysis, Wadi Degla

\section{Introduction}

The world is witnessing a recent climate change event, in particular the rise of temperature and heavy rain in locations that were not previously witnessed, and Egypt is one of those countries that are located in the dry regions, but the past twenty years have witnessed change and precipitation and the occurrence of flash floods that led to the destruction of the Basic structure and roads. There is no doubt that global 
climate change has an impact on the frequency and magnitude of flash floods. [1]

Heavy rainstorms frequently generate flash floods in the harsh Eastern Desert and Sinai, causing damage to roads and basic tourism infrastructure. [2-8]. Heavy rains in hot deserts are characterised by high speed and short duration, with a quick peak of discharge. [9]. The roads and human activity along the Red Sea and Gulf of Suez coasts are severely impacted by the periodic flash floods [10]. Several more studies in Egypt focused on flood risks in numerous locations. (e.g. [11-14].

Morphometry is the science of calculating the earth's surface area, landform proportions, and shape. The term "morphometry" relates to the process of calculating the earth's surface area, landform proportions, and form. A detailed morphometric investigation of watersheds can be used to learn more about the geomorphic history of the area, the drainage network development and estimating and predicting its behavior under heavy rainfall conditions, and for calculating the potential flash flood hazard for downstream settlements [15-19]. On the 24th and 25th of April 2018, a strong rainstorm caused flash flooding in the study region, with rainfall totals of 31.3 in Wadi Degla [20]. This flood has severely harmed the infrastructure in the Wadi Degla protectorate, where runoff water has filled most of gate facilities, parking area and remove signposts and visitor tracks.

The purpose of this study is to apply GIS techniques to identify the potential flood hazard of Wadi Degla based on combining values of different geomorphic parameters and to estimate the degree of risk and to mitigate from this hazard.

\section{Materials and Methods}

\subsection{Site Description}

The Wadi Degla basin is located on the northwestern edge of the eastern Desert. It extends eastward at (29 58 00N, 3139 00 E) to west at (29 5500 N, 311900 E) Figure 1. Wadi Degla drains its water down to the Nile River. The basin extends 37 $\mathrm{km}$ long, from east to west. In 1999 Small portion of the basin was officially declared a protected area of around $30 \mathrm{~km}^{2}$.

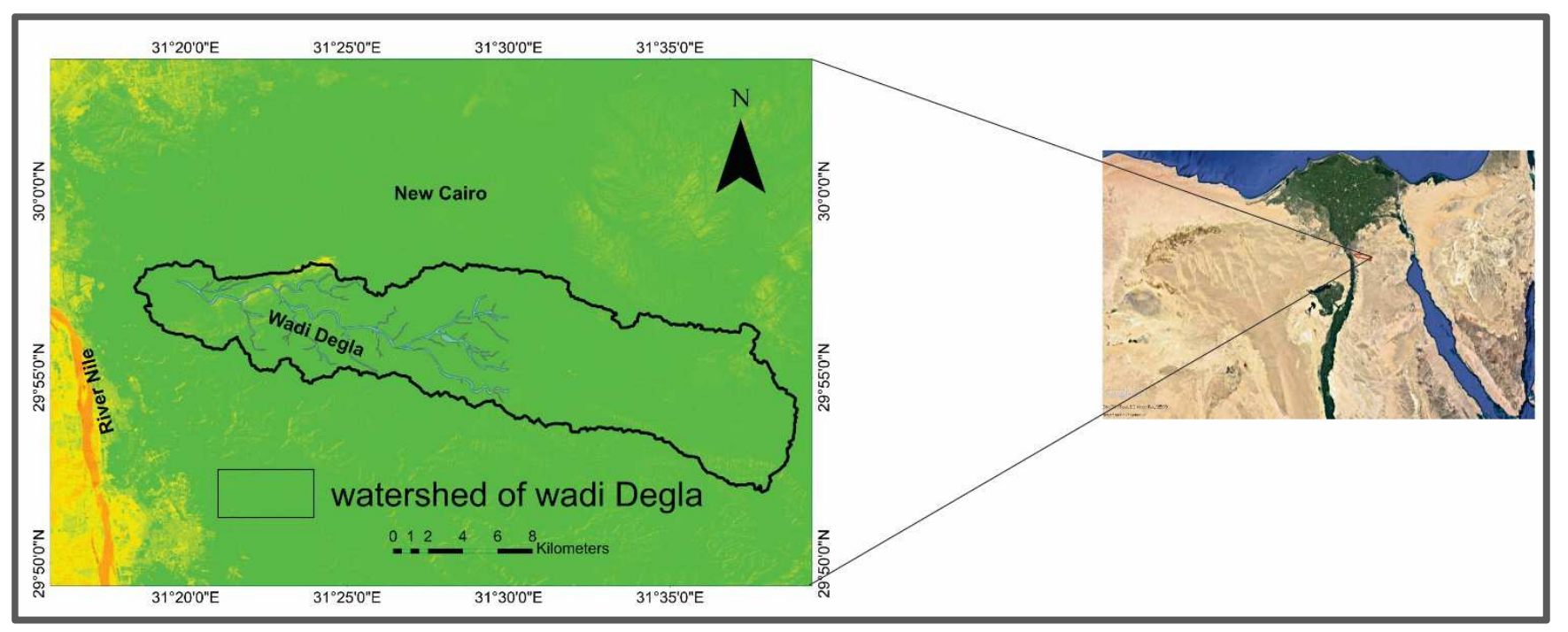

Figure 1. The Location Map of the study area.

The average annual rainfall in the catchment area is around $13 \mathrm{~mm}$ and the regular maximum rainfall was $25 \mathrm{~mm} /$ day. The maximum rainfall recorded in the area was $38 \mathrm{~mm}$ in 1908 (the region occasionally saw severe rainfall episodes (typically $38 \mathrm{~mm} /$ day) over a short period of time). In June, the average maximum temperature is around $34.7^{\circ} \mathrm{C}$, while the average minimum temperature is around $9^{\circ} \mathrm{C}$ in January, with relative humidity ranging between 40 and 56 percent [21]. Geologically, the rock units exposed in the study area of middle and Upper Eocene age and are made up of carbonate and intercalation of marly limestones with bands of dolomitic limestones at the base and marly at the top. Severe flashfloods hit the Wadi Degla throughout the last 10 years. In the Wadi Degla's lower watershed, heavy thunder storms occur between November and March, bringing considerable flooding and inundation. Flooded water remains in the rounded pit in the eastern part of the Wadi at the area known by name Degla canyon for a few months before evaporation.

\subsection{Methodology}

Geographic information systems (GIS) are applied in a variety of sectors, including urban and regional planning [22, $23]$, criminology [24, 25] and natural science [26, 27]. Wadi Degla morphometric analysis was performed using GIS, which is an appropriate tool for studying the morphological analysis. The morphometric parameters were then identified with a $30 \mathrm{~m}$ precision using the SRTM DEM. The hydrology tool in ArcGIS software version 10.2 processes DEM data. A variety of data and approaches are utilized to extract the drainage map. Filling DEM data gaps, flow direction, flow accumulation, conditional, stream order, and streaming features to convert raster stream order to vector data are all 
part of the digital DEM raw data processing. Drainage maps are used to construct the approach for quantitative estimation of morphometric parameters, which is based on the formula proposed by [28-34] summarized in Table 1 and applied by numerous authors such as [35-41]. In this work, morphometric characteristics were examined in order to calculate the flood risk. within Wadi Degla watershed using the approach of ElShamy [11].

Table 1. Methodology adapted for calculation of morphometric parameters.

\begin{tabular}{lll}
\hline Morphometric Parameters & Formula & References \\
\hline Stream Order $(\mathrm{U})$ & Hierarchical rank & {$[29]$} \\
Stream Number $(\mathrm{Nu})$ & $\mathrm{Nu}=\mathrm{N} 1+\mathrm{N} 2+\ldots \mathrm{Nn}$ & {$[30]$} \\
Stream Length $(\mathrm{Lu})$ & $\mathrm{Length}$ of the stream $(\mathrm{km})$ & {$[30]$} \\
Bifurcation Ratio $(\mathrm{Rb})$ & $\mathrm{Rb}=\mathrm{Nu} /(\mathrm{Nu}+1)$ & {$[31]$} \\
Form Factor Ratio $(\mathrm{Ff})$ & $\mathrm{Ff}=\mathrm{A} / \mathrm{Lb} \mathbf{2}^{\wedge}$ & {$[32]$} \\
Elongation Ratio $(\mathrm{Re})$ & $\mathrm{Re}=(2 / \mathrm{Lb})^{*}(\mathrm{~A} / \pi)^{\wedge}$ & {$[31]$} \\
Texture Ratio $(\mathrm{Rt})$ & $\mathrm{Rt}=\mathrm{N} 1 / \mathrm{P}$ & {$[30]$} \\
Circularity Ratio $(\mathrm{Rc})$ & $\mathrm{Rc}=4 \mathrm{pA} / \mathrm{P} 2$ & {$[33]$} \\
Stream Frequency $(\mathrm{Fc})$ & $\mathrm{Fs}=\mathrm{Nu} / \mathrm{A}$ & {$[32]$} \\
Drainage Density $(\mathrm{Dd})$ & $\mathrm{Dd}=\mathrm{Lu} / \mathrm{A}$ & {$[32]$} \\
Total basin relief $(\mathrm{H})$ & $\mathrm{H}=\mathrm{Z}-\mathrm{z}$ & {$[34]$} \\
Relief Ratio $(\mathrm{Rh})$ & $\mathrm{Rh}=\mathrm{H} / \mathrm{Lb}$ & {$[35]$} \\
\hline
\end{tabular}

Two alternative methods were used to identify the hazardous coming from the Wadi Degla watersheds. The first technique is based on the relationship between drainage density and bifurcation ratio, while the second way is based on the link between drainage frequency and bifurcation ratio. Each method employs a three-zoned diagram; zone A denotes a high possibility for floods and low Potential for groundwater recharge; zone $\mathrm{B}$ denotes a moderate flash flood possibility; and zone $\mathrm{C}$ denotes a low possibility for floods.

\section{Result and Discussions}

\subsection{Linear Morphometric Parameters}

\subsubsection{Stream Order}

Stream ordering is a method of assigning links in a stream network to a numerical order. In this study the various stream segments of the drainage basin have been ranked according to stream ordering system of [28]. The unbranched fingertip tributary is built as 1 st order; 2 nd order tributary receives 1 st order tributary branches, 3rd order stream receives one or more 2nd order tributaries and may also receive 1st order branches. A stream of 4 th order receives branches of 3 rd order and also of lower orders and so on. The tributaries of the Wadi Degla basin are found to be of fifth order, as illustrated in in Table 2.

\subsubsection{Stream Number and Stream Length}

Stream number refers to the number of stream channels in a given order. [29]. For the Wadi Degla tributaries the stream numbers and lengths of each order were measured and was found to have a 5th order stream that includes 1075 total stream numbers in the catchment, of which 542 stream numbers were identified in 1st order with length $258.8 \mathrm{Km}$, 235 stream numbers in 2nd order with $40.1 \mathrm{Km}, 126$ and 48.5 $\mathrm{Km}$ stream numbers in 3rd order, 60 stream numbers in 4 th order with length $22.1 \mathrm{~km}$ and 112 fifth order streams and $31.2 \mathrm{~km}$ respectively as seen on Table 2 below and Figure 2. The overall number of stream segments is clearly reducing as the stream order in the basin increases. Even the drainage patterns of the basin's stream network were primarily dendritic, indicating textural homogeneity (Carbonate rocks). Table 2.

Table 2. Linear aspect of Wadi Degla basin.

\begin{tabular}{|c|c|c|c|c|c|c|c|}
\hline \multirow{2}{*}{ Stream order } & \multirow{2}{*}{ Stream number } & \multicolumn{3}{|c|}{ Stream length km } & \multirow{2}{*}{ Stream length ratio } & \multirow{2}{*}{ Bifurcation ratio } & \multirow{2}{*}{$\begin{array}{l}\text { Length of overland } \\
\text { flow }(\mathrm{km})\end{array}$} \\
\hline & & Total & Mean & Cumulative & & & \\
\hline 1 & 542 & 258.8 & 0.48 & 0.48 & & 2.3 & \\
\hline 2 & 235 & 40.1 & 0.17 & 0.65 & 2.8 & 1.9 & 0.22 \\
\hline 3 & 126 & 48.5 & 0.38 & 1.03 & 0.4 & 2.1 & \\
\hline 4 & 60 & 22.1 & 0.37 & 1.4 & 1 & 0.53 & \\
\hline 5 & 112 & 31.2 & 0.27 & 1.7 & 1.4 & & \\
\hline Total & 1075 & 400.7 & 0.37 & & & Mean $=1.7$ & \\
\hline
\end{tabular}

\subsubsection{Bifurcation Ratio}

The bifurcation ratio is the ratio of the number of stream segments in one order to the number of segments in the following higher level [30]. It is a crucial measure that indicates a basin's water carrying capacity and related flood potentiality [42]. According to [28], the bifurcation ratio typically varies from 2 to 5 for drainage basins where geological formations do not disrupt the drainage pattern. Lower bifurcation ratios, on the other hand, are indicative of structurally less disturbed watersheds with no drainage pattern distortion. According to [43] the bifurcation ratio ranging between 3 and 5 indicate the natural drainage system within a homogenous rock. The reference [44] had noted that the lower the bifurcation ratio, the higher the risk of flooding, particularly of parts and not the entire basin.
The morphometric analysis data of the bifurcation ratio from the study area indicates that for the fifth and first orders they range from 0.53 to 2.3 , with a mean value of 1.7 respectively The low average mean bifurcation ratio of the basin under study of 1.7 is an indication that parts of its segments (the fifth order) are liable to flooding. This actually confirmed during the reconnaissance survey in Figure 3.

\subsubsection{Length of Overland Flow}

Known as the maximum length of surface water flow created by rain over the earth until it's focused into specified stream channels and equals half the drainage density [29]. Reference [45] was classified the overland flow length into three classes including low $(<0.2)$, moderate $(0.2-0.3)$ and high $(>0.3)$ While [46] state that a low Length of overland flow value indicates high relief, short flow paths, more runoff, 
and less infiltration, resulting in increased susceptibility to flash flooding, [47] state that a high value indicates high relief, short flow paths, more runoff, and less infiltration, resulting in increased susceptibility to flash flooding. A high Length of overland flow number, on the other hand, indicates gentle slopes and long flow routes, which means more infiltration and less runoff. Table 2 shows that the overland flow length in the Wadi Degla drainage basin is $0.2 \mathrm{~km} / \mathrm{km}^{2}$, indicating modest surface runoff Its mean that Wadi Degla high relief with short flow paths and more venerable risk flooding expected

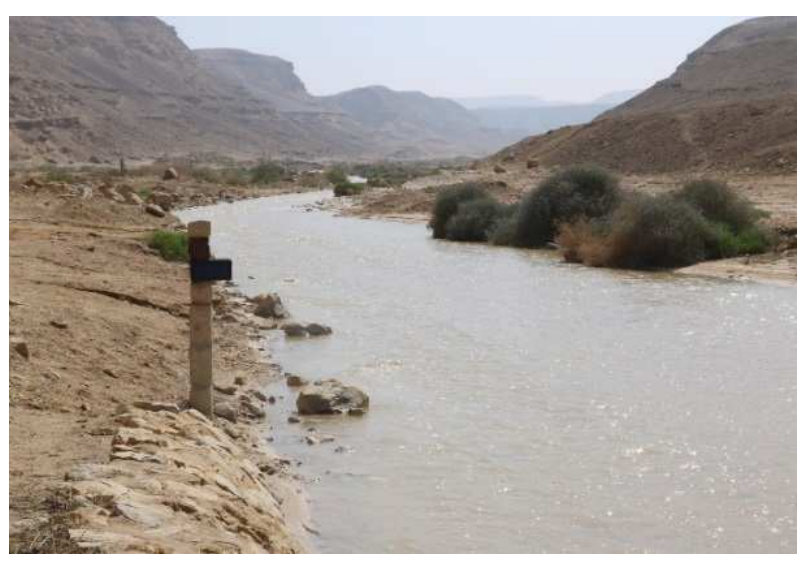

Figure 2. Stream order in Wadi Degla Basin.
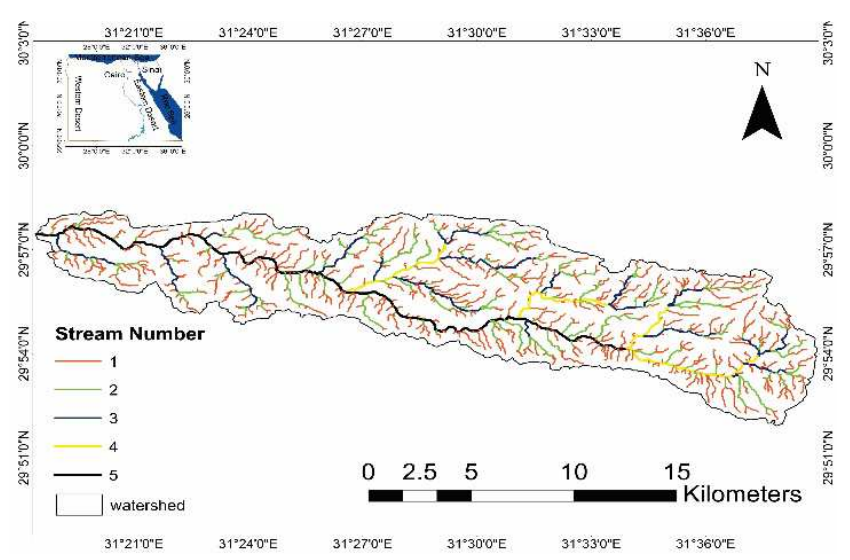

Figure 3. Collection of Flooding in the main pass of the Wadi.

\subsection{Areal Aspect Morphometric Parameters}

\subsubsection{Stream Frequency}

The total number of stream segments of all orders per unit area is known as the stream frequency or channel frequency [31].

The frequency of the Stream, according to reference [47], is mostly determined by the lithology of the basin and reflects the drainage network structure. Hydraulic conductivity, seepage rate, and terrain are all factors that influence this.

The higher value indicates the basin has more low relief and greater stream number. The presence of a large number of streams in a basin shows that the topography is still young and undergoing erosion, but the presence of less streams suggests that the stream is maturing [48]. In mountain locations, higher slopes and more rainfall increase the frequency of streams, but in plateau environments, low permeability and less available surface flow reduce the value [49]. while,[50] reported that low stream frequency values ( 1.0 to 3.5$)$ indicate that the high stream frequencies range between (4 to 10) indicate low impermeability and greater surface runoffs. Larger surface runoff and a steeper ground surface are associated with higher stream frequency [51]. Table 3 shows the frequency of stream segments in the study area, which is 6.05 per square kilometer. Due to the existence of ridges on both sides of the valley, as well as a higher slope from the surface, this value refers to low impermeability of carbonate rocks and increased surface runoff.

\subsubsection{Drainage Density}

The total length of streams divided by the drainage basin area per unit area is known as drainage density. According to Horton, drainage density is an expression of the tightness of channel spacing inside a basin, and it reveals how near the channels are to spacing [29].

Drainage density is an important landform characteristic that allows for numerical measurements of runoff potential and landscape segmentation. Low drainage density suggests extremely resistant or permeable subsoil material, dense vegetation, and low relief. High drainage density denotes subsurface material that is weak or impermeable, sparse vegetation, and high relief with fine drainage texture. The low drainage density indicates permeable sub-surface, the vegetation is dense with relief poor and coarse drainage texture [28, 52-56]. High drainage density also leads to a highly dissected drainage basin with a fast hydrological reaction to rainfall events, while low drainage density leads to a poorly drained basin with a slow hydrologic response [19].

Table 3. Areal aspect parameters of Wadi Degla.

\begin{tabular}{ll}
\hline Morphometric Parameters & Results \\
\hline Stream Frequency & 6.05 \\
Drainage density & 2.26 \\
Texture ratio & 11.5 \\
Elongation ratio & 0.41 \\
Circularity ratio & 0.26 \\
Form Factor ratio & 0.13 \\
\hline
\end{tabular}

The hydraulic conductivity of the underlying soil is inversely related to drainage density. According to Table 3, the drainage density of the study region is $2.26 \mathrm{~km}^{2} / \mathrm{km}^{2}$, suggesting high drainage densities indicating weak permeable near-surface lithology with moderate drainage and moderate to high relief. This value also suggests highly dissected steep terrain with impervious underlying rocks, particularly limestone or dolomitic limestone. According to [57], the High drainage density value indicates less permeable rock in the bed surface, high slope, and high water flow regimes.

\subsubsection{Texture Ratio}

The drainage texture ratio was described by reference [29] as the total number of stream segments of all kinds per perimeter of the area. Drainage texture is a measure of channel spacing closeness that is determined by the lithology, 
infiltration capabilities, and relief features of a given terrain [58]. Reference [59] classified drainage texture into five grades: extremely coarse (2), coarse (2-4), moderate (4-6), fine (6-8) and very fine $(>8)$ drainage texture. The basic lithology, infiltration capacity, climate, rainfall, vegetation, rock, soil type, and terrain relief aspect are all key factors in the morphometric analysis of drainage [60]. The drainage texture value of the Wadi Degla basin in the current study is 11.5 , which indicates that the catchment region has a very fine texture, low permeability (carbonate rocks), limited vegetation, and low infiltration capacity, with high relief and high runoff. Similar observation was reported by [61] who concluded that the high ratio basins indicate little infiltration and complicated relief with very low permeability.

\subsubsection{Elongation Ratio}

The elongation ratio was defined by reference [30] as the ratio of the diameter of a circle of the same area as the drainage basin to the basin's maximum length. [62] classified the elongation ratio into three categories: less elongated (0.7), oval $(0.8-0.9)$, and round $(>0.9)$. Values near unity are frequently linked with modest relief, whereas values in the range of $0.6-0.8$ are typically associated with high relief and steep ground slope [28]. In this study, the elongation ratio is 0.41 , indicating that the catchment fits into the elongated categories with strong relief according to [62]. Figure 2.

\subsubsection{Circularity Ratio}

The Circularity Ratio [32] is the ratio of a basin's surface area to the surface area of a circle with the same circumference as the basin's perimeter. Stream length, stream frequency, geological features, land cover, climate, relief, and basin slope all influence circularity ratio values, which range from zero (for a line) to one (for a circle) [63]. A circular basin with a high circularity ratio has moderate to high roughness and high infiltration, whereas a circular basin with a low circularity ratio has less elongation, lower roughness, and low infiltration [64]. As indicated in Table 3, the circularity ratio for the Wadi Degla basin in the study area is 0.26 . This lower number implies that it is elongated, has a moderate to high relief, and a drainage system that is less structurally managed.

\subsubsection{Form Factor Ratio}

The ratio of basin area to basin length square is known as the form factor ratio [31]. The form factor is a measure that is used to forecast the flow intensity of a watershed in a specific area, and it has a direct relationship to peak discharge [29]. The form factor ranges from 0 for a lengthy basin to 1 for a fully round basin. In Table 3, the Wadi Degla has a form factor ratio of 0.13 . The Wadi Degla catchment appears to be elongated based on this form factor value. The lower number suggests that the Wadi Degla's elongated shape makes it more sensitive to flood flows than the circular catchment area.

\subsection{Relief Aspect}

The study of three-dimensional features involving area, volume, and height of vertical dimension of landforms to examine distinct geo-hydrological characteristics is related to the relief aspects of drainage basin analysis [19]. Total basin relief and relief ratio were regarded as relief aspects metrics.

\subsubsection{Total Basin Relief}

The total relief of a basin is the difference in elevation between the highest point of a watershed and the lowest point on the valley floor [28]. It is a characteristic that effects the flood pattern and the amount of silt that can be transported by a stream [33]. It is critical to comprehending the basin's denudational characteristics [65]. The overall basin relief of the watershed in Wadi Degla is $528 \mathrm{~m}$, with the greatest and lowest elevations being $597 \mathrm{~m}$ (a.s.1) in the eastern portion of the study area and $69 \mathrm{~m}$ (a.s.l) in the western half of the study area, respectively Figure 4.

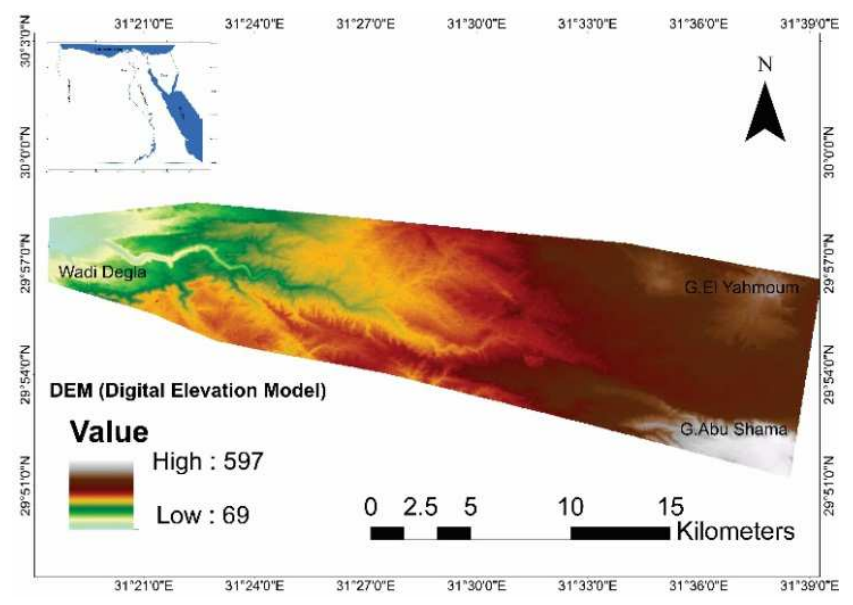

Figure 4. Digital Elevation Model of Wadi Degla catchment.

\subsubsection{Relief Ratio}

The relief ratio [30] is defined as the ratio of basin relief to basin length. It's computed by dividing a basin's relief by its length. The relief ratio is a dimensionless quantity that measures the average decline in height per unit length of basin, according to reference [66]. The relief ratio with a higher value indicates the presence of steep slope and high basin relief whilst, lower values indicate the existence of low slope and high resistant rocks $[67,68]$. The relief ratio of Wadi Degla basin is $5.6 \mathrm{~m} / \mathrm{km}$ This high value reflects a basin with significant-high relief and a steep slope Figure 4.

\subsection{Flash Flood Risk Assessment}

According to the classification proposed by [11] Figure 5, the basin is classified into three categories based on the bifurcation ratio, drainage density, and stream frequency. This is a category (A) with a high risk of flash flooding. Category (B) has a moderate risk of flash flooding, whereas category (C) has a low risk of flash flooding. The three parameters were plotted in El-Shamy's diagram (Figure 5). As a result of the plot of stream frequency vs bifurcation ratio, the Wadi Degla catchment region is classified as Zone A, suggesting a high risk of flash flooding. On the other hand, a plot of drainage density vs bifurcation ratio revealed that the study's catchment region falls within Area A, indicating a significant risk of flash flooding. The overall hazard degree for this catchment will be 
high possibility for flash floods. This confirmed during field visit where the effect of flood in the infrastructure of protected area such as tracks, signposts and main gate. Figure 6 .

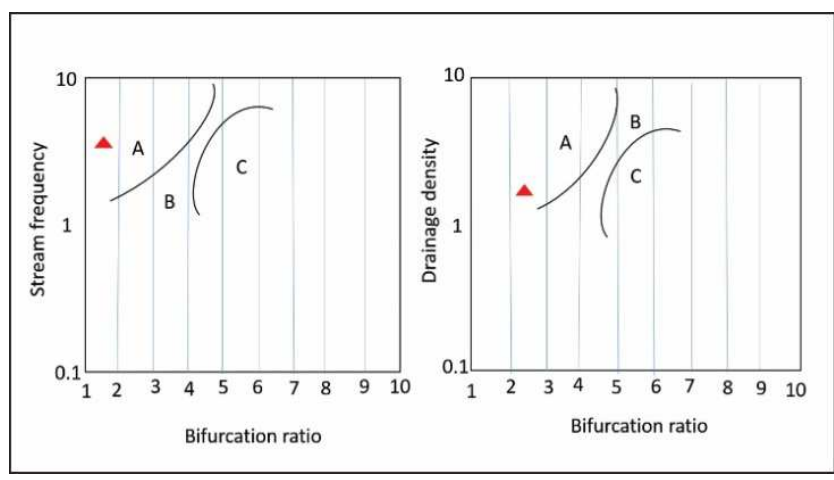

Figure 5. Flooding susceptibility of Wadi Degla based on El-Shamy's approach.

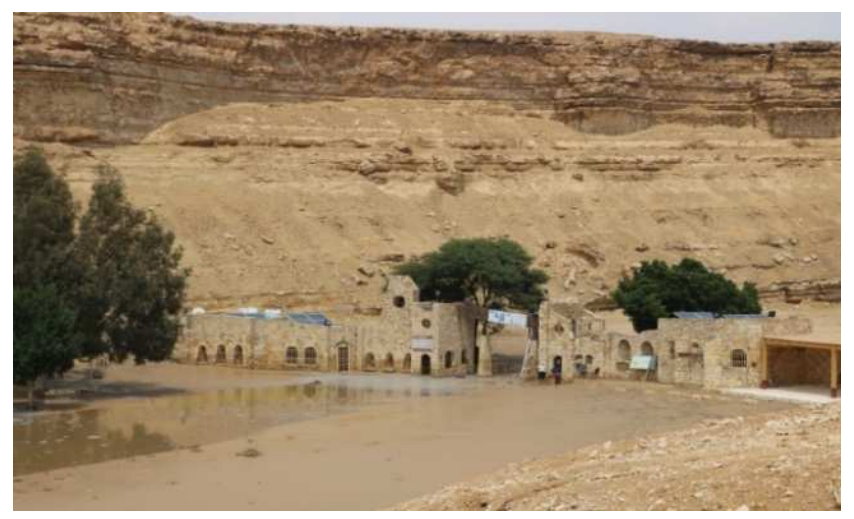

Figure 6. Main gate of Wadi Degla Protected area affected by flood water.

\section{Conclusion and Recommendations}

The Wadi Degla watershed's flash flood risk was assessed using GIS-based morphometry and field measurements. The bifurcation ratio, stream frequency, and drainage density estimated parameters aid in understanding numerous basin characteristics, and these parameters were verified using ElShamy method to predict flash flood assessment. The findings indicate a high risk of flash flooding in the research area. The findings point to a high risk of flash flooding in the study area. As a result, the study suggests that precautionary steps be taken to reduce the effects of flooding include (1) prevent establishment any construction in the course of the wadi or nearby the Wadi Degla and (2) regular maintenance of the pass of the wadi and encourage the Ministry of water resources to establish dams to control the flash flood hazards in addition to (3) protect of visitors by closed the protected area during rainfall.

\section{Acknowledgements}

We would like to provide our gratitude for Geologists Bakr Mohamed Manager of Wadi Degla Protected area and all the staff of protected area especial thanks to Mr. Rashed Salama for efforts during field visits.

\section{References}

[1] Prama, M., Omran, A., Schröder, D., \& Abouelmagd, A. (2020). Vulnerability assessment of fash foods in Wadi Dahab Basin, Egypt Environmental Earth Sciences (2020) 79: 114.

[2] Abdel-Lattif, A., \& Sherief, Y. (2012). Morphometric analysis and flash floods of Wadi Sudr and Wadi Wardan, Gulf of Suez, Egypt: using digital elevation model. Arab J Geosci (2012) 5: 181-195.

[3] Tahaa, M., Elbarbaryb, S., Naguibc, D., \& El-Shamy, I. (2017) Flash flood hazard zonation based on basin morphometry using remote sensing and GIS techniques: A case study of Wadi Qena basin, Eastern Desert, Egypt. Remote Sensing Applications: Society and Environment, 8, 157-16.

[4] Abuzied, S. \& Mansour, B. (2019). Geospatial hazard modeling for the delineation of flash flood-prone zones in Wadi Dahab basin, Egypt. Journal of Hydroinformatics. 21 (1): 180-205.

[5] Elsadek, W., Ibrahim, M., \& Mahmod, W. (2018). Flash Flood Risk Estimation of Wadi Qena Watershed, Egypt Using GIS Based Morphometric Analysis. App. Envi. Res. 40 (1): 41-50.

[6] Youssef, A., Pradhan, B., \& Hassan. A. (2011). Flash flood risk estimation along the St. Katherine road, southern Sinai, Egypt using GIS based morphometry and satellite imagery. Environ Earth Science, 62, 611-623.

[7] El Osta. M., El Sabri, M., \& Masoud, M. (2016). Estimation of flash flood using surface water model and GIS technique in Wadi El Azariq, East Sinai, Egypt Nat. Hazards Earth System. Sciences, 1-51.

[8] Thabet, H., Mohamed A., \& Hassan, H. (2016). Geomorphologic and hydrogeologic studies for some basins in the area between Abu Ghusun and Bernice, South Eastern Desert, Egypt" Egypt. J. Aquat. Biol. \& Fish, 20 (2): 123144.

[9] Ashour., M. (2002). Flash flood in Egypt - a case study of Durunka village-Upper Egypt. Soc geog Egypt. 75.

[10] Hassan., O. (2000). Salient Geoenvironmental parameters of Ras Malaab-Abu Zenima Area, Gulf of Suez, Egypt, with an emphasis on flash flood potential and mitigative measures; Egypt. J Remote Sens Space Sci. 3, 37-58.

[11] El-Shamy, I. (1992a). Recent recharge and flash flooding opportunities in the Eastern Desert, Ann Geol Surv, Egypt, 323-334.

[12] El-Etr, H., \& Ashmawy, M. (1993). Flash flood vulnerability and mitigation of the Red Sea basins between Latitudes 24410 and 2526 0. Proc. Internat. Conf. " 30 years Coop. Geol. Surv., Egypt, Cairo, 335-351.

[13] Ashmawy, M. (1994). Assessment of flash flood potential of the Red Sea drainage basins along the Qena-Safaga highway, Eastern Desert, Egypt ITC Journal, 2, 119-128.

[14] Youssef, A., \& Hegab, M. (2005). Using geographic information systems and statistics for developing a database management system of the flood hazard for Ras Gharib area, Eastern Desert, Egypt, The Fourth International Conference on the Geology of Africa, Assiut, Egypt, 2, 1-15. 
[15] Lara, G., Perucca, L., \& Rothis, M. (2018). Morphometric, Geomorphologic and Flood Hazard Analysis Of An Arid Mountain River Basin, Central Pre-Andes Of Argentina. Southwestern South America, Geogr. Fis. Dinam. Quat. 83-97.

[16] Farhan, Y., Anaba, O., \& Salim, A. (2016). Morphometric Analysis and fash foods assessment for drainage basins of the Ras En Naqb Area South Jordan Using GIS. J Geosci Environ Protect. 4 (6): 9-33.

[17] Abdalla F., El-Shamy I., Bamousa, A., Mansour, A., Mohamed, A., \& Tahoon, M. (2014). Flash floods and groundwater recharge potentials in arid land alluvial basins, southern red sea coast, Egypt. Int J Geoscience, 5, 971-982.

[18] Pal, B., Samanta, S., \& Pal, D. (2012). Morphometric and hydrological analysis and mapping for watut watershed using remote sensing and GIS techniques. Int J Adv Eng Technol. 1 (6): $357-368$

[19] Hajam, R., Hamid, A., \& Bhat, S. (2013). Application of morphometric analysis for geo-hydrological studies using geo-spatial technology - A case study of Vishav drainage basin Hydrology: Current Research. 4 (3): 1-12.

[20] Morad, N., Youssef, N., \& Ibrahem, S. (2020). Assessment Of Flash Flood "April 2018" And Its Effect On Wadi Degla And Wadi El-Halazouni - East Cairo - Egypt. Egyptian J. Desert Res. 70 (1) 25-57.

[21] Megahed, H. \& El Bastawesy. M. (2020). Hydrological problems of flash floods and the encroachment of wastewater afecting the urban areas in Greater Cairo, Egypt, using remote sensing and GIS techniques. Bulletin of the National Research Centre, 44 (188): 1-14.

[22] Dai, F., Lee, C., \& Zhang, X. (2001). GIS-based geo-environmental evaluation for urban land-use planning: a case study: Engineering Geology, 61 (4): 257-271.

[23] Janowski, P. (1989). Mixed data multicriteria evaluation for regional planning: A systematic approach to the decision-making process. Environment and Planning. A (21): 349-362.

[24] Brantingham, P., \& Brantingham, P., (1995). Location quotients and crime hotspots in the city, in Block, C., Dabdoub, M., and Fregly, S., eds., Crime analysis through computer mapping, Washington, D.C., Police Executive Research Forum, 129-149.

[25] Chainey, S., \& Ratcliffe, J. (2005). GIS and Crime Mapping, Hoboken, N. J., John Wiley \& Sons, 442.

[26] Carrara, A., Cardinali, M., Detti, R., Guzzetti, F., Pasqui, V., \& Reichenbach, P., (1991). GIS techniques and statistical models in evaluating landslide hazard: Earth Surface Processes and Landforms. 16, 427-445.

[27] Goodchild, M. (1993). The state of GIS for environmental problem solving, in Goodchild, M. F., Parks, B. O., and Steyaert, L. T., eds., Environmental Modeling with GIS, New York, Oxford University Press, 8-15.

[28] Strahler, A. (1964). Quantitative geomorphology of drainage basins and channel networks. In: Chow VT (ed) Handbook of applied hydrology. McGraw-Hill, New York, 439-476.

[29] Horton, R. (1945). Erosional development of streams and their drainage basins: Hydrophysical approach to quantitative morphology. Bull. Geol. Soc. Amer. 56, 275-370.
[30] Schumm, S. (1956). Evolution of drainage systems and slopes in badlands at Perth Amboy, New Jersey. Geol Soc Am Bull. 67, 597-646.

[31] Horton, R. 1932. Drainage-basin characteristics Eos. Trans Am Geophys Union, 13, 350-361.

[32] Miller, V. (1953). A quantitative geomorphic study of drainage basin characteristics in the clinch mountain area virginia and tennessee. Columbia Univ, New York.

[33] Hadley, R. \& Schumm, S. 1961. Sediment sources and drainage basin characteristics in upper Cheyenne river basin. US geological Survey Water supply paper, 1531 B, 198.

[34] Schumm, S. (1963). Sinuisity of alluvial rivers in the great plains. Bulletin Geological Society American, 74, 1089-1100.

[35] Strahler, A. (1952). Dynamic Basis of Geomorphology. Geological Society of America Bulletin, 63, 938.

[36] Strahler, A. (1968). Quantitative geomorphology. In: Fairbridge RW (ed) Encyclopedia of geomorphology. Reinhold Book Crop, New York.

[37] Schumn, S. (1932). Evolution of Drainage systems and slopes in Badlansat Perth Amboy, New Jersy. Geological Society of America, Bulletin. 67, 597-646.

[38] Smart, J., \& Surkan, A. (1967). The relation between mainstream length and area in drainage basins. Water Resource Research. 3 (4): 963-974.

[39] Avena, G., Giuliano, G., \& Palmieri, E. (1967). Quantitative evaluation of the hierachization and evolution of drainage networks. Bull Soc Geol Italy. 86, 781-796.

[40] Waugh, D., (1995). Geography: An integrated approach. 2nd Ed. Chapter-3, Morphometry of drainage basins, 51-62.

[41] Gupta, B. (1999). Engineering Hydrology, 3rd Ed. Runoff, 239.

[42] Joji, V., Nair, A., \& Baiju, K. (2013). Drainage basin delineation and quantitative analysis of Panamaram Watershed of Kabani River Basin, Kerala using remote sensing and GIS. J Geol Soc India, 82, 368-378.

[43] Kale, VS., \& Gupta, A. (2001). Introduction to Geomorphology. Orient Longman New Delhi. Sangam Books Ltd, 278.

[44] Chorley, R. J., 1969. Introduction to Physical Hydrology. Methuen and Co. Ltd., Suffolk, 211.

[45] Chandrashekar, H., Lokesh, K., Sameena, M., Jyothi, R.,\& Ranganna, G. (2015). GIS -Based Morphometric Analysis of Two Reservoir Catchments of Arkavati River, Ramanagaram District, Karnataka. Aquatic Procedia, 4, 1345-1353.

[46] Vinutha, D., \& Janardhana, M. (2014). Morphometry of the Payaswini Watershed, Coorg District, Karnataka, India, Using Remote Sensing and GIS Techniques. International Journal of Innovative Research in Science, Engineering and Technology. 3 (5): 516-524.

[47] Rai, p., Mishra, V., \& Mohan, K. (2017). A study of morphometric evaluation of the Son basin, India using geospatial approach Remote Sensing Applications: Society and Environment, 7, 9-20.

[48] Oruonye, E. (2016). Morphometry and Flood in Small Drainage Basin: Case Study of Mayogwoi River Basin in Jalingo, Taraba State Nigeria, Journal of Geography, Environment and Earth Science International. 5 (1): 1-12. 
[49] Bali, R., Agarwal, K., Ali, S., Rastogi, S., \& Krishna, K. (2011) Drainage morphometry of Himalayan Glacio-fluvial basin, India: hydrologic and neotectonic implications. Environ Earth Sci 66 (4): 1163-1174.

[50] Melton, M. (1958). Correlation structure of morphometric properties of drainage system and their controlling agents. Journal of Geology, 66: 442-460.

[51] Vittala, S., Govindaiah, S, Gowda, H. (2004). Morphometric analysis of sub-watersheds in the Pavagada area of Tumkur District, South India using remote sensing and GIS techniques. J Ind Soc Remote Sens. 32 (4): 351-362.

[52] Langbein, W. (1947). Topographic characteristics of drainage basins, U.S. Geological Survey Water Supply. 968 (C): 125-157.

[53] Nag, S. (1998). Morphometric analysis using remote sensing techniques in the Chaka sub-basin, Purulia district, West Bengal. J Indian Soc Remote Sens, 26, 69-76.

[54] Nag, S., \& Chakraborty, S. (2003). Influence of rock types and structures in the development of drainage network in hard rock area. J Indian Soc Remote Sens. 31 (1): 25-35.

[55] Ahmed, S., Chandrashekarppa, K., Raj, S., Nischitha, V., \&Kavitha, G. (2010). Evaluation of morphometric parameters derived from ASTER and SRTM DEM-a study on Bandihole Sub-watershed Basin in Karnataka. J Indian Soc Remote Sens, $38,227-238$.

[56] Ramaiah, S., Gopalakrishna, G., Vittala, S., \&Najeeb, K. (2012). Morphometric analysis of sub-basins in and around Malur Taluk, Kolar District, Karnataka using remote sensing and GIS techniques. Nat Environ Pollut Technol. 11 (1): 89-94.

[57] Mahala, A. (2020). The signifcance of morphometric analysis to understand the hydrological and morphological characteristics in two diferent morpho-climatic settings Applied Water Science, 10 (33): 1-17.

[58] Gutema, D., Kassa, T., \& Sifan, A. (2017). Morphometric Analysis to Identify Erosion Prone Areas on The Upper Blue Nile Using GIS (Case Study of Didessa and Jema Sub-Basin, Ethiopia). International Research Journal of Engineering and Technology. 4 (8): 1773-1784.
[59] Smith. K. (1950) Standards for grading texture of erosional topography. Am J Sci. 248, 655-668.

[60] Nageswara, R., Swarna, L., Arun, K. \& Hari, K. (2010). Morphometric Analysis of Gostani River Basin in Andhra Pradesh State, India Using Spatial Information Technology. International Journal of Geomatics and Geosciences, 1, 179-187.

[61] Kumar, N. (2013). Morphometric analysis of river catchments using remote sensing and GIS (a case study of the Sukri River, Rajasthan). International Journal of Scientific and Research Publications, 3 (6): 1-6.

[62] Iqbal. M., Sajjad, H., \& Bhat, F. (2013). Morphometric Analysis of Shaliganga Sub Catchment, Kashmir Valley, India Using Geographical Information SystemInternational Journal of Engineering Trends and Technology. 4 (1): 10-21.

[63] Bali, R., Agarwal, K., Ali, S., Rastogi, S., \& Krishna, K. (2012) Drainage morphometry of Himalayan Glacio-fluvial basin, India: hydrologic and neotectonic implications. Environ Earth Science, 66, 1163-1174.

[64] Arabameri, A., John P., Blaschke, T., Pradhan, B., \& Tien Bui, D. (2020). Morphometric Analysis for Soil Erosion Susceptibility Mapping Using Novel GIS-Based Ensemble Model. Remote Sensing. 12 (5): 1-24.

[65] Sreedevi, P., Subrahmanyam, K., \& Ahmed, S. (2004). The significance of morphometry analysis for obtaining groundwater potential zones in a structurally controlled terrain. Environmental Geology. 47, 417-420.

[66] Fryirs, K., and Brierley, G. (2013). Geomorphic analysis of river systems: An approach to reading the landscape. West Sussex: Wiley Blackwell Publication. 29-62.

[67] Arulbalaji, P. \& Gurugnanam, B. (2017). Geospatial tool-based morphometric analysis using SRTM data in Sarabanga watershed, Cauvery River, Salem district, Tamil Nadu, India Applied Water Science. 7 (7): 3875-3883.

[68] Rahel, H. (2020). Multiple Morphometric Characterization and Analysis of Malakan Valley Drainage Basin Using GIS and Remote Sensing, Kurdistan Region, Iraq American Journal of Water Resources 8 (1): 38-47. 